This is an author produced version of a paper published in Documenta Ophthalmologica. This paper has been peer-reviewed but does not include the final publisher proof-corrections or journal pagination.

Citation for the published paper:

Kjellstrom U, Kjellstrom S, Bruun A, Andreasson S, Ponjavic V. "Retinal function in rabbits does not improve 4-5 months after terminating treatment with vigabatrin"

Documenta Ophthalmologica, 2006, Vol: 112, Issue: 1, pp. 35-41. http://dx.doi.org/10.1007/s10633-006-0004-z

Access to the published version may require journal subscription. Published with permission from: Springer 


\section{Retinal function in rabbits does not improve 4-5 months after terminating treatment with vigabatrin}

Ulrika Kjellström M.D., Sten Kjellström M.D., Anitha Bruun Ph.D., Sten Andréasson M.D., Ph.D. \& Vesna Ponjavic M.D., Ph.D.

Dept. of Ophthalmology, University of Lund, Lund, Sweden.

Subtitle: Vigabatrin irreversibly reduces retinal function in rabbits

\section{Correspondence and proofs to:}

Dr. Ulrika Kjellström, Department of Ophthalmology, University of Lund, S 22185 Lund, Sweden Fax: +46-46-13 9045

E-mail: ulrika.kjellstrom@skane.se 
Keywords: Vigabatrin, electroretinogram, immunohistochemistry, drug toxicity.

\begin{abstract}
Purpose: We have previously reported changes in retinal function and histopathology in rabbits treated with vigabatrin. The purpose of the present study was to evaluate retinal function and histopathology of retina in rabbits 4-5 months after terminating vigabatrin medication. Methods: Five rabbits were treated with a daily per oral dose of vigabatrin during 12-13 months. After terminating treatment an observation period of 4-5 months followed. Six rabbits receiving water served as controls. Standardized full-field electroretinograms were performed every 6-8 weeks, using a Burian-Allen bipolar contact lens. After 18 months the rabbits were sacrificed and the morphology of the sectioned retina was studied. The antibodies used for staining were GABA, GFAP, GAD, and vimentin. Results: After 1213 months of treatment full-field ERG was reduced in all rabbits treated with vigabatrin. There was a statistically significant difference in the dark adapted cone b-wave amplitude between treated animals and controls (Wilcoxon signed ranks test, $\mathrm{p}=0.043$ ). This difference was consistent also 4-5 months after terminating treatment. Immunohistology of the sectioned retina demonstrated no significant difference in immunoreactivity between treated animals and controls. All treated rabbits demonstrated elevated serum concentration of the drug during medication. Conclusion: Four to five months after terminating treatment with vigabatrin the rabbit full-field ERG remains reduced in isolated cone bwave amplitude indicating that vigabatrin induced retinal dysfunction may be irreversible. However, immunohistology is normal after a period without treatment, implying that the previously described changes in retinal morphology and glial cell activity are reversible, and probably exist only during treatment.
\end{abstract}




\section{Introduction}

In 1997 the first reports were presented of severe, persistent visual field defects associated with the use of vigabatrin, an antiepileptic drug that is still used for treating seizures in patients with complex epilepsy and in children with infantile spasm [1-6]. As approximately 30-40\% [7-9] of adult patients receiving vigabatrin develop visual field defects, we suspect that also children treated with this drug may do so, however, visual field testing in children under 10-12 years of age is problematic and unreliable. We have therefore previously recommended electroretinography as an objective and reliable method for monitoring these patients, as the visual field defect correlates well with a reduced retinal function assessed with the full-field electroretinogram (ERG) [10]. This finding has been confirmed by other research groups [8,11-13].

The mechanism of action of vigabatrin involves the inhibition of the $\gamma$-aminobutyric acid (GABA) transaminase enzyme, leading to increased levels of GABA in the brain. GABA is an important modulatory neurotransmitter. A previous report has demonstrated that vigabatrin in rabbit retina causes changes in immunohistopathology characterized by an enhancement of the glial cells located in the peripheral parts of the retina, which may explain the concentric visual field defect found in patients taking the drug [14]. These changes in immunohistopathology were also correlated with a reduced cone b-wave amplitude in the rabbit full-field ERG, a result very similar to the reduced ERG in vigabatrin treated patients.

Several clinical studies have previously been conducted aiming to determine whether the vigabatrin caused visual field defect is irreversible or not. Most of these studies have demonstrated neither improvement nor worsening 1-47 months after treatment was stopped, suggesting that the visual field 
defect is irreversible but not progressive[15-21]. In addition, some of these investigators have assessed ERGs, which showed irreversible changes [15,17,18,21]. The most consistent ERG results were a reduction in photoptic b-wave amplitude, a reduction in amplitudes of the oscillatory potentials and a reduction in amplitudes of the $30 \mathrm{~Hz}$ flicker ERG. Some investigations also showed a reduction in the scotopic b-wave amplitude [15,17].

There are, however a few studies indicating some reversibility. In a recent study Fledelius [22] found a significant improvement, but not full recovery, in the visual fields of patients 6-26 months after full drug withdrawal. Similar results have been reported by Krakow et al. [23]. A recent study [24] has shown increased amplitudes in both photopic and scotopic oscillatory potentials after discontinuation of vigabatrin, but they interpret these changes as a non-toxic pharmacological effect of vigabatrin on GABAergic amacrine cells in the inner retina.

Thus, it is still not clarified whether vigabatrin caused changes in retinal function and histology are reversible or not. The aim of the present study was therefore to investigate if rabbit retina improves in function and histology several months after terminating treatment with vigabatrin.

\section{Material and methods}

\section{Subjects and medication}

Seven rabbits, nine months of age at entry to the study, were treated with a daily per oral dose of vigabatrin during 12-13 months. The doses of medication ranged between 250-1250 mg and had to be continuously adjusted since some of the rabbits suffered from serious drug side effects (loss of appetite), when receiving high doses of vigabatrin. The medication was administrated orally as a water solution, using a syringe. Once a month, blood samples were collected from the ear vein of all the rabbits to measure the serum concentration of vigabatrin in order to ensure proper medication. After terminating treatment an observation period of 4-5 months followed. Nine rabbits receiving water 
served as controls and were examined according to the protocol used for the treated rabbits. Two treated rabbits and three controls died unexpectedly during the study and were therefore excluded. The study was conducted with approval of the ethical committee for animal research at the University of Lund. The research procedures were in accordance with the ARVO statement for the use of animals in ophthalmic and vision research.

On entry to the study all rabbits were examined with standardized full-field ERG [25], on three separate occasions before randomization. After randomization and initiation of treatment, full-field ERGs were performed every 4-8 weeks. Medication was carried out during 12-13 months and then discontinued. The rabbits were further followed regularly with full-field ERG for another 4-5 months.

After 18 months the rabbits were sacrificed and the morphology of the sectioned retina was studied.

\section{Electrophysiology}

Full-field ERGs were recorded with a Nicolet analysis system (Nicolet Biomedical Instruments, Madison Wisconsin) as described previously [14]. The examinations were conducted according to the International Society for Clinical Electrophysiology of Vision (ISCEV) standards [26]. The right eye was tested after maximal pupil dilation with topical 1\% cyclopentolate hydrochloride, and after at least 30 minutes of dark adaptation. A Burian-Allen bipolar ERG contact lens electrode was applied on the topically anesthetized cornea together with a subcutaneous ground electrode on the neck. Responses were obtained with a wide band filter $(-3 \mathrm{~dB}$ at $1 \mathrm{~Hz}$ and $500 \mathrm{~Hz}$ ), stimulating with single full-field flashes (30 $\mu$ s) with dim blue light (Wratten filters \#47, 47A and 47B) and with white light (integrated luminance $0.81 \mathrm{~cd}-\mathrm{s} / \mathrm{m}^{2}$ ). Cone responses were obtained with $30 \mathrm{~Hz}$ flickering white light (integrated luminance $0.81 \mathrm{~cd}-\mathrm{s} / \mathrm{m}^{2}$ ) averaged from 20 sweeps with no background illumination and with background illumination (34cd m-2). Cone responses were also obtained with single full-field flashes

with white light (integrated luminance $3.93 \mathrm{~cd}-\mathrm{s} / \mathrm{m}^{2}$ ) with background illumination (34cd $\mathrm{m}-2$ ). The 
referred luminance of the four different light stimuli has been measured on the light reflected from the Ganzfeld sphere. At each stimulus intensity the recordings were repeated to ensure reproducibility (ie until two successive identical curves were obtained). All rabbits were sedated with Hypnorm (fentanylcitrate $0.315 \mathrm{mg} / \mathrm{ml}$ and fluanisone $10 \mathrm{mg} / \mathrm{ml}$ ) during the examination.

\section{Tissue preparation}

The rabbits were euthanized by an intravenous overdose of barbiturates. The eyes were enucleated within one minute and fixed for 30 minutes in freshly prepared 4\% phosphate buffered formaldehyde, generated from paraformaldehyde (Merck, Darmstadt, Germany) at pH 7.4 in 0.1 M Sörensen’s phosphate buffer (primary and secondary NaHPO; Merck). The eyes were then transected at the ora ciliaris retinae. The anterior segment, lens and vitreous body were discarded. The posterior segment was post fixed in the same fixative for 3.5 hours, at $4^{\circ} \mathrm{C}$. The tissue was then rinsed and cryoprotected by transferring it stepwise through solutions of increasing concentrations of sucrose (10, 15 and 20\%) in the Sörensen's buffer. The eyecups were then divided into two parts by a vertical incision from the superior to the inferior retinal margins comprising the optic disc. The two halves were embedded in Yazulla media (30\% egg albumen and $3 \%$ gelatine in water) and the sectioning $(12 \mu$ in the cryostat $-21^{\circ} \mathrm{C}$ ) started at the central part towards the peripheral part of the eye. The sections were collected on chrome alum coated slides, air dried, and stored at $-20^{\circ} \mathrm{C}$ until used.

\section{Immunohistochemistry}

The sections were thawed and washed in $0.1 \mathrm{M}$ sodium phosphate buffered saline pH 7.2 (PBS) with 0.25\% Triton X-100 (PBST). For diluting the primary and secondary antibodies, 1\% bovine serum albumin was added in PBST. The sections were then incubated in the primary antibodies (Table I) for 16-18 hrs, in $4^{\circ} \mathrm{C}$. After 1 hour in room temperature, the slides were rinsed in PBST and further incubated in the fluorescent secondary antibodies (1:200), appropriate for the primary antibody, for 45 min in darkness. After rinsing, the slides were mounted in Vectashield, (Vector Laboratories, Inc, 
Burlingham). The slides were examined using immunofluorescence imaging and photographed by a digital camera (Nikon Eclipse 800). The antibodies used for staining of retinal sections were GABA, GFAP, GAD, and vimentin.

\section{Results}

\section{Medication}

In all rabbits treated with vigabatrin the serum analyses, measured by high-performance liquid chromatography (HPLC), demonstrated an elevated drug concentration, while the controls had undetectable levels of the drug.

\section{Electrophysiology}

After 12-13 months of treatment the full-field ERG was reduced in all five rabbits treated with vigabatrin (Table 2). The amplitudes of the rod isolated response, and of the combined cone-rod response to flashes of white light, both dark and light adapted, were not significantly affected during treatment. However, at the end of the treatment period, there was a statistically significant difference in the dark adapted cone b-wave amplitude between the treated animals and the controls (Wilcoxon signed ranks test, $\mathrm{p}=0.043$ ). This difference was consistent also 4-5 months after terminating treatment (Wilcoxon signed ranks test, $\mathrm{p}=0.043$ ). The full-field ERG responses to all stimulations, from rabbit nr. 5 are shown in Fig. 1.

\section{Histology}

There was no significant difference in immunoreactivity for the four different antibodies between the treated animals and the controls. One of the treated animals had a slightly enhanced GFAP immunoreactivity, but this was seen also in one of the controls. We could not detect any changes in 
Müller cell morphology, or alterations in immunohistologic staining, of the type previously reported in rabbit retina during treatment with vigabatrin [14].

\section{Discussion}

The antiepileptic drug vigabatrin is known to cause typical concentric visual field defects in at least 30$40 \%$ [7-9] of treated patients. Moreover it is well documented that vigabatrin medication gives electrophysiological changes such as a reduction in photopic b-wave amplitudes in the full-field ERG $[8,10-13]$. Similar reductions in cone b-wave amplitudes in the $30 \mathrm{~Hz}$ flicker ERG are also seen in rabbits receiving vigabatrin [14]. Several studies have demonstrated a reduced ERG also after discontinuation of medication $[15,17,18,21]$. Duboc et al [27] have performed a study in rats, demonstrating a decrease in photopic ERG amplitudes in both single flash (by $40 \%$ ) and in modified flicker responses; 5, 10 and $15 \mathrm{~Hz}$ (by 37\%) after 45 days of vigabatrin treatment when compared to control animals. These pathological responses remain unchanged also after a 43-day recovery period without treatment.

The before mentioned observations are consistent with the results of the present study. Both during treatment and after 4-5 months without any medication, the treated rabbits show an unchanged reduction of the cone b-wave in the $30 \mathrm{~Hz}$ flicker ERG. These results indicate that vigabatrin causes irreversible changes in the photopic electroretinogram which can be interpreted as a dysfunction in one or more levels in the cone photoreceptor pathway. Neal et al. [28] have demonstrated GABA accumulation in retinal glial cells, mainly Müller cells, in rats receiving vigabatrin suggesting toxic levels of GABA as a cause of retinal damage. The increased concentration of GABA in rat retinal tissue has been confirmed in another investigation by Sills et al. [29]. They have also demonstrated a pronounced accumulation of vigabatrin in retina compared to brain tissue, considering this as a plausible cause of the visual field constriction reported in patients. 
In the study by Duboc et al. [27] immunohistological examination of sectioned rat retina indicates severe alterations in retinal architecture both immediately after drug withdrawal and after a wash out period of 45 days. PNA staining reveals disorganized cone outer and inner segments and a decrease in cone density throughout the whole retina. The peripheral parts were however most affected. In that study there was also enhanced GFAP expression in Müller glial cells around the areas of damaged cone photoreceptors. We have previously shown immunohistological changes in retina of rabbits examined during vigabatrin treatment [14]. These results suggest a pathological process in the Müller cells, which were short, stubby and fragmented with swollen end-feet in vimentin staining and also demonstrated enhanced GFAP immunoreactivity as a sign of tissue damage. There was also significant pathology of the IPL demonstrating poor staining with GAD and enhanced GABA-immunoreactivity.

In the present study we have performed the same immunohistochemical labelling process in retinal sections from rabbits euthanized 4-5 months after drug withdrawal. Immunofluorescens imaging shows no significant difference in immunoreactivity between treated animals and controls. This means that the pathological changes in Müller cells and IPL previously documented in rabbits receiving vigabatrin have been normalized and exist only during treatment. The electrophysiological changes, characterized by a decrease in the cone b-wave amplitude of the $30 \mathrm{~Hz}$ flicker ERG, are, however, still seen 4-5 months after withdrawal of medication, although the immunohistological signs of damaged Müller glial cells are no longer evident. Our findings indicate that the glial reaction might be reversible. However, there must be some form of retinal damage causing the remaining decrease in the photopic ERG. There seems to be a permanent retinal damage consistent with the irreversible visual field defects seen in patients. The results of Duboc et al. [27] suggest there is a probability that vigabatrin medication results in permanent damage to cone photoreceptors, which is in accordance with our observed alterations in the photopic ERG. At the time of analysis we did not have a specific marker for staining of cones. 
Further studies may reveal that both cones and Müller cells are involved in the pathogenesis of vigabatrin induced retinopathy.

We conclude that five months after terminating treatment with vigabatrin, the rabbit full-field ERG remains reduced in isolated cone b-wave amplitude, indicating that the vigabatrin induced retinal dysfunction may be irreversible. However, immunohistology of the inner retina and the glial cells is normal after a period without treatment, implying that the previously described changes in retinal morphology and glial cell activity are reversible, and probably exist only during treatment. 


\section{Acknowledgements}

We thank Ing-Marie Holst, Boel Nilsson for skillful technical assistance. This study was supported by grants from Stiftelsen Synfrämjandets Forskningsfond, Kronprinsessans Margaretas Arbetsnämnd, the Royal Physiographic Society, the Swedish Medical Research Council (projects no. 73X-12597-03A, 14P-12964-01AK), the $2^{\text {nd }}$ ONCE international award for new technologies for the blind and the Faculty of Medicine at the University of Lund. 


\section{References}

1. Eke T, Talbot JF, Lawden MC. Severe persistent visual field constriction associated with vigabatrin. Br Med J 1997; 314: 180-181.

2. Backström JT, Hinke RL, Flicker MR. Severe persistent visual field constriction associated with vigabatrin. Br Med J 1997; 314: 1694-1695.

3. Blackwell N, Hayllar J, Kelly G. Severe persistent visual field constriction associated with vigabatrin (letter). Br Med J 1997; 314: 1694.

4. Harding GA. Severe persistent visual field constriction associated with vigabatrin (letter). Br Med J 1997; 314: 1694.

5. Wilson EA, Brodie MJ. Severe persistent visual field constriction associated with vigabatrin (letter). Br Med J 1997; 314: 1693.

6. Wong ICK, Mawer GE, Sander JWAS. Severe persistent visual field constriction associated with vigabatrin. Br Med J 1997; 314: 1694-1695.

7. Kälviänen R, Nousianen I, Mänyjärvi M, Nikoskelainen E, Partanen J, Partanen K, Reikkinen P. Vigabatrin, a GABAergic antiepileptic drug, cause concentric visual field defects. Neurology 1999;53:922-926

8. Miller NR, Johnson MA, Paul SR, Girkin CA, Perry JD, Endres M, Krauss GL. Visual dysfunction in patients receiving vigabatrin: clinical and electrophysiological findings. Neurology 1999;53:2082-2087

9. Nicolson A, Leach JP, Chadwick DW, Smith DF. The legacy of vigabatrin in a regional epilepcy clinic. J Neurol Neurosurg Psychiatry 2002;73:327-329.

10. Ponjavic V, Andréasson S. Multifocal ERG and full-field ERG in patients on long-term vigabatrin medication. Doc Ophthalmol 2001; 102: 63-72.

11. Harding GFA, Wild JM, Robertson KA, Rietbrock S, Martinez C. Separating the retinal electrophysiologic effects of vigabatrin. Treatment versus field loss. Neurology 2000;55:347-352.

12. Comaish IF, Gorman C, Brimlow GM, Barber C. Orr GM, Galloway NR. The effects of vigabatrin on electrophysiology and visual fields in epileptics: a controlled study with a discussion of possible mechanisms. Doc Ophthalmol 2002;104:195-2129. 
13. McDonagh J, Stephen LJ, Dolan FM, Parks S, Dutton GN, Kelly K, Keating D, Sills GJ, Brodie MJ. Peripheral retinal dysfunction in patients taking vigabatrin. Neurology 2003;61:1690-1694.

14. Ponjavic V, Gränse L, Kjellström S, Andréasson S, Bruun A. Alterations in electroretinograms and retinal morphology in rabbits treated with vigabatrin. Doc Ophthalmol 2004; 108: 125-133.

15. Johnson MA, Krauss GL, Miller NR, Medura M, Paul SR. Visual function loss from vigabatrin. Effect of stopping the drug. Neurology 2000;55:40-45.

16. Nousiainen I, Mantyjarvi M, Kalviainen R. No reversion in vigabatrin-associated visual field defects.Neurology 2001;57:1916-1917.

17. Coupland SG, Zackon DH, Leonard BC, Ross TM. Vigabatrin Effect on Inner Retinal Function. Ophthalmology 2001;108:1493-1498.

18. Graniewski-Wijnands, van der Torren K. Electro-ophthalmological recovery after withdrawal from vigabatrin. Doc Ophthalmol 2002;104:189-194.

19. Schmidt T, Rüther K, Jokiel B, Pfeiffer S, Tiel-Wilck K, Schmitz B. Is visual field constriction in epilepsy patients treated with vigabatrin reversible? J Neurol 2002;249:1066-1071.

20. Newman WD, Tocher K, Acheson JF. Vigabatrin associated visual field loss: a clinical audit to study prevalence, drug history and effects of drug withdrawal. Eye 2002;16:567-571.

21. Hardus P, Verduin W, Berendschot T, Postma G, Stilma J, Van Veelen C. Vigabatrin:longterm follow-up of electrophysiology and visual field examinations. Acta Ophthalmol. Scand 2003;81:459-465.

22. Fledelius HC. Vigabatrin-associated visual field constriction in a longitudinal series. Reversibility suggested after drug withdrawal. Acta Ophthalmol. Scand. 2003;81:41-45.

23. Krakow K, Polizzi G, Riordan-Eva P, Holder G, Macleod W, Fish D. Recovery of visual field constriction following discontinuation of vigabatrin. Seizure 2000;9:287-290.

24. Westall CA, Nobile R, Morong S, Buncic RJ, Logan WJ, Panton CM. Changes in the electroretinogram resulting from discontinuation of vigabatrin in children. Doc Ophthalmol 2003;107:299-309.

25 Gjörloff K, Andréasson S, Ehinger B. Standardized full-field electroretinography in rabbits. Doc Ophthalmol 2004;109:163-168. 
26. Marmor MF, Holder GE, Seelinger MW, Yamamoto S. International Society for Clinical Electrophysiology of Vision. Standard for clinical electroretinography (2004 update). Doc Ophthalmol 2004;108: 107-114.

27. Duboc A, Hanoteau N, Simonutti M, Rudolf G, Nehlig A, Sahel JA, Picaud S. Vigabatrin, the GABA-transaminas inhibitor, damages cone photoreceptors in rats. Ann Neurol 2004;55:695-705.

28. Neal MJ, Cunningham JR, Shah MA, Yazulla S. Immunocytochemical evidences that vigabatrin in rats causes GABA accumulation in glial cells of the retina. Neurosci Lett 1989;98:29-32.

29. Sills GJ, Butler E, Forrest G, Ratnaraj N, Patsalos PN, Brodie M. Vigabatrin, but not gabapentin or topiramat, produces concentration-related effects on enzymes and intermediates of the GABA shunt in rat brain and retina. Epilepsia 2003;44:886-892. 


\section{Legends}

\section{Table 1}

Antibodies used for immunohistological staining of retinal sections.

\section{Table 2}

ERG data demonstrating responses (b-wave amplitudes) to five different stimulations before (upper row) and after (middle row) treatment with vigabatrin, as well as 4-5 months after discontinuation of medication (lower row). The results indicate selective and irreversible reduction of the cone response.

\section{Figure 1}

Full-field ERG from rabbit nr. 5 before and after treatment with vigabatrin. The ERG traces demonstrate that the rod response remains unaffected by vigabatrin, while the cone b-wave amplitude is significantly reduced by the drug, also after several months of wash-out. 
Table 1

\begin{tabular}{|c|c|c|c|c|}
\hline Antibody & Antigen & Target & Poly/monoclonal & Source \\
\hline Vimentin & Purified Vimentin & $\begin{array}{c}\text { Müller } \\
\text { Cells }\end{array}$ & Mono & $\begin{array}{c}\text { Chemicon } \\
\text { International }\end{array}$ \\
\hline $\begin{array}{c}\text { GFAP } \\
\text { Glial fibrillary } \\
\text { acidic protein }\end{array}$ & Purified GFAP & Glial cells & Mono & $\begin{array}{c}\text { Chemicon } \\
\text { International }\end{array}$ \\
\hline $\begin{array}{c}\text { GAD } \\
\text { Glutamic acid } \\
\text { decarboxylase }\end{array}$ & $\begin{array}{c}\text { Recombinant-DNA } \\
\text { GAD }\end{array}$ & $\begin{array}{c}\text { GABAergic } \\
\text { cells }\end{array}$ & Poly & $\begin{array}{c}\text { Chemicon } \\
\text { International }\end{array}$ \\
\hline $\begin{array}{c}\text { GABA } \\
\text { Gamma amino } \\
\text { butyric acid }\end{array}$ & GABA & $\begin{array}{c}\text { GABAergic } \\
\text { cells }\end{array}$ & Mono & $\begin{array}{c}\text { Chemicon } \\
\text { International }\end{array}$ \\
\hline
\end{tabular}


Table 2

\begin{tabular}{|c|c|c|c|c|c|c|}
\hline Rabbit & Time & \begin{tabular}{|c|} 
Blue single \\
flash \\
Darkadapted \\
Amplitude \\
$(\mu V)$
\end{tabular} & $\begin{array}{c}\text { White single } \\
\text { flash } \\
\text { Darkadapted } \\
\text { Amplitude } \\
(\mu \mathrm{V})\end{array}$ & $\begin{array}{c}\text { 30Hz Flicker } \\
\text { Darkadapted } \\
\text { Amplitude } \\
(\mu \mathrm{V})\end{array}$ & $\begin{array}{l}\text { 30Hz Flicker } \\
\text { Lightadapted } \\
\text { Amplitude } \\
(\mu \mathrm{V})\end{array}$ & $\begin{array}{l}\text { White single } \\
\text { flash } \\
\text { Lightadapted } \\
\text { Amplitude } \\
(\mu V)\end{array}$ \\
\hline 1 & \begin{tabular}{|l} 
Before \\
treatment \\
After \\
discontinuation \\
5 months after \\
discontinuation
\end{tabular} & $\begin{array}{l}76 \\
126 \\
103\end{array}$ & $\begin{array}{l}135 \\
181 \\
130\end{array}$ & $\begin{array}{l}17,3 \\
11,8 \\
9,1\end{array}$ & $\begin{array}{l}13,9 \\
9,0 \\
9,9\end{array}$ & $\begin{array}{l}109 \\
100 \\
63\end{array}$ \\
\hline 2 & $\begin{array}{l}\text { Before } \\
\text { treatment } \\
\text { After } \\
\text { discontinuation } \\
5 \text { months after } \\
\text { discontinuation }\end{array}$ & $\begin{array}{l}87 \\
63 \\
56\end{array}$ & $\begin{array}{l}160 \\
111 \\
88\end{array}$ & $\begin{array}{r}28,5 \\
9,2 \\
14\end{array}$ & $\begin{array}{c}27,6 \\
9,0 \\
12\end{array}$ & $\begin{array}{l}125 \\
64 \\
72\end{array}$ \\
\hline 3 & $\begin{array}{l}\text { Before } \\
\text { treatment } \\
\text { After } \\
\text { discontinuation } \\
5 \text { months after } \\
\text { discontinuation }\end{array}$ & $\begin{array}{l}70 \\
73 \\
86\end{array}$ & $\begin{array}{l}134 \\
108 \\
104\end{array}$ & $\begin{array}{c}14 \\
10,6 \\
8,3\end{array}$ & $\begin{array}{l}18 \\
8,9 \\
6,0\end{array}$ & $\begin{array}{l}89 \\
57 \\
52\end{array}$ \\
\hline 4 & $\begin{array}{l}\text { Before } \\
\text { treatment } \\
\text { After } \\
\text { discontinuation } \\
5 \text { months after } \\
\text { discontinuation }\end{array}$ & $\begin{array}{l}85 \\
48 \\
72\end{array}$ & $\begin{array}{l}138 \\
92 \\
111\end{array}$ & $\begin{array}{l}11 \\
7,3 \\
8,6\end{array}$ & $\begin{array}{l}11,8 \\
6,5 \\
6,0\end{array}$ & $\begin{array}{l}87 \\
40 \\
61\end{array}$ \\
\hline 5 & $\begin{array}{l}\text { Before } \\
\text { treatment } \\
\text { After } \\
\text { discontinuation } \\
5 \text { months after } \\
\text { discontinuation }\end{array}$ & $\begin{array}{l}69 \\
51 \\
33\end{array}$ & $\begin{array}{l}100 \\
78 \\
92\end{array}$ & $\begin{array}{r}14,3 \\
6,7 \\
10,7\end{array}$ & $\begin{array}{r}11,9 \\
5,4 \\
7,8\end{array}$ & $\begin{array}{l}69 \\
40 \\
52\end{array}$ \\
\hline $\begin{array}{l}6 \text { controls } \\
\mathrm{MD} \pm \mathrm{STD}\end{array}$ & & $118 \pm 51$ & $169 \pm 56$ & $21,3 \pm 6,5$ & $17,2 \pm 6,4$ & $95 \pm 29,7$ \\
\hline
\end{tabular}


